\title{
Investigation of the Prevalence of Legionella in Apartment Houses
}

\author{
Jung-Hee Lee*, Myoung-Ki Park, Young-Su Kim, Bu-Geon Lim, Hye-Yeoun Lee, Young-Sug Kim \\ Team of Immunodiagnosis, Gyeonggi-province Institute of Health and Environment, Suwon 16205, Republic of Korea
}

\author{
Corresponding \\ Jung-Hee Lee, Research officer for health \\ Team of Immunodiagnosis, \\ Gyeonggi-province Institute of Health \\ and Environment, Suwon 16205, \\ Republic of Korea \\ Phone : +82-31-250-5005 \\ Fax : +82-31-250-5008 \\ E-mail : tenbora@gg.go.kr
}

Received : March 8, 2021

Revised : June 16, 2021

Accepted : June 21, 2021

No potential conflict of interest relevant to this article was reported.

Copyright (C) 2021 Journal of Bacteriology and Virology

(C) This is an Open Access article distributed under the terms of the Creative Commons Attribution Non-Commercial

License

(http://creativecommons.org/

license/by-nc/3.0/).
Apartment houses is typical residential type of South Korea and was presumed the route of infection of legionellosis. But data on the management status and the risk of infection about apartment houses is lack. Therefore, we tried to investigate of prevalence and risk factors of Legionella in apartment houses. This study examined 111 samples collected from 37 apartment houses (37 hot water, 37 cold water, 37 sediments inside of faucets) and 142 hot water samples collected from 142 public-use facilities. As a result, nine of 37 apartment houses were contaminated with Legionella in only hot water and two were contaminated with Legionella in hot water and faucets. The prevalence of Legionella in hot water of apartment houses and public-use facilities was $29.7 \%$ and $20.4 \%$, respectively. However, the percentages of bacteria exceeding 1,000 CFU/L was $13.5 \%$ and $16.2 \%$ in respectively. The analysis of the prevalence of Legionella by age of apartment houses showed $6.7 \%$ for 1 to 10 years, 33.3\% for 10 to 20 years and $53.8 \%$ exceed 20 years. Analysis of the serotype of isolated Legionella was that two were L. pneumophila sg1, seven were L. pneumophila sg2-14, and four were Legionella spp.

Key Words: Legionella, Apartment houses, Public-use facilities, Serotype

\section{INTRODUCTION}

레지오넬라균은 1976년 7월에 미군 퇴역 군인 협회인 아메리카 군단의 모임에 참석한 사 람들 사이에서 발견되었는데 당시 221 명이 감염되고 34 명이 사망하였다. 그 후 원인균이 그동안 알려지지 않았던 세균인 것으로 확인되었고 이 세균에 의한 병은 레지오넬라증 (Legionnaires' disease, 재향군인병)이라 이름 붙여졌다 (1).

국내에서는 1984년 7월 서울 고려대병원 중환자실에서 중환자 및 중환자실 근무 의료진 26 명 중 23명에게 원인불명의 집단폐렴이 발생하여 처음 알려지기 시작하였다. 그 당시 레 지오넬라균(Legionella spp.)은 분리하지 못하였으나, 혈청학적 검사로 Legionella gormanii (L. gormani)에 의한 레지오넬라증 임이 밝혀졌다 (2). 그 후로 집단발생은 보고되지 않았 으나, 급성 백혈병, 신장이식, 전신성 홍반성 낭창 등의 기저질환이 있어 면역억제요법을 받고 있는 중이거나 퇴원 후에 발생된 사례가 간헐적으로 보고되고 있다.

레지오넬라균은 자연에서 지하수, 호수, 하천 등 환경수에서 낮은 농도로 존재하며, 수중에 존재하는 담조류와 아메바 체내, 배관 내에 있는 생물막(biofilm)에서 자란다 (3). 레지오 넬라균의 주요 감염경로는 비말에 의한 호흡기 감염이며, 이 세균은 오염원에서 공기를 통 해 최소 $6 \mathrm{~km}$ 반경까지 퍼질 수 있다 (3). 
우리나라에서는 2000년부터 레지오넬라 폐렴(Legionnaire's disease)과 폰티악열(Pontiac fever)로 대표되는 레지오넬라증(Legionellosis) 을 전수감시 대상 3급 법정감염병으로 지정하여 의료기관의 신고를 통한 발생 감시를 지속하고 있다. 2000년부터 2005년까지 레지오 넬라증 신고 건수는 50건을 넘지 않는 수준으로 유지되었으나, 2016년 128건으로 증가한 이후 2018년에 305건 2019년에 474건(인 구 10만 명당 0.92명)으로 매년 신고건수가 증가하고 있다 (4).

최근 레지오넬라증 신고건수가 지속적으로 증가하는 원인은 명확하지 않으나 인구 고령화, 기후 변화, 진단 및 신고율 향상 등이 영향을 미쳤을 것으로 추정하고 있다. 특히 국내에서는 레지오넬라증 유전자검사법인 중합효소연쇄반응(Polymerase Chain Reaction, PCR) 검사가 2014년 11월부터 보험급여 적용되기 시작한 것도 레지오넬라증 신고건수 증가에 영향을 미쳤을 것으로 추정된다 (5).

레지오넬라증은 3급 법정감염병으로 질병관리청을 주축으로 전국의 시·도 등 관련기관이 검사를 실시하고 있다. 질병관리청에서 발행한 2018 년도 감염병 역학조사 연보에 따르면 국내에서 발생된 레지오넬라증 감염경로를 추정한 결과, 의료기관 감염 $16.8 \%$, 숙박시설 감 염 $2.3 \%$, 가정 내 감염 $6.0 \%$, 지역사회 감염 $26.5 \%$, 감염경로 추정 불가 $48.3 \%$ 로 나타났다 (5).

이 자료에서 레지오넬라증 추정 감염경로 중 가정 내 감염이 $6.0 \%$ 로 추정되고 있음에도 불구하고 아직도 주거시설에 대한 레지오넬라균 관리현황과 거주자의 감염 위험성은 파악되지 못하고 있는 상황이다 (6). 이러한 주거시설 종류 중에서 전국적으로 아파트가 차지하는 비 율은 약 $62.3 \%$ 로 가장 높다 (7). "아파트(Apartment houses)"는 주택으로 쓰는 층수가 5개 층 이상인 공동주택을 말하며 (8), "공동주 택”이란 건축물의 벽 · 복도 - 계단이나 그 밖의 설비 등의 전부 또는 일부를 공동으로 사용하는 각 세대가 하나의 건축물 안에서 각각 독 립된 주거생활을 할 수 있는 구조로 된 주택을 말한다 (9). 또한 「감염병의 예방 및 관리에 관한 법률 시행령」 제24조 13항은 소독을 해야 하는 시설에는 300 세대 이상의 공동주택을 포함하고 있으며 (10), 이를 근거로 질병관리청 호흡기감염병 관리지침은 아파트 등 공동주 택을 연 1회 이상 레지오넬라증 예방을 위한 정기검사 대상시설에 포함시키고 있다 (3).

그러나 지자체에서 검사대상 선정 시 고위험시설을 우선순위로 계획을 수립하다 보니 우선순위에 밀려 이러한 권고사항은 잘 지켜지지 않고 있어, 아파트의 레지오넬라균 오염실태 조사가 시급하다고 판단되어 본 연구를 수행하였다.

\section{MATERIALS AND METHODS}

\section{검체 수집}

본 연구는 2020년 1월부터 12월 사이에 경기남부지역 아파트 거주자 대상으로 무작위로 연구에 참여하도록 요청하여 이를 수락한 37명 에게 검체를 제공받아 수행되었다. 서로 다른 단지의 37 개 아파트 별로 동일한 수도꼭지에서 나오는 온수, 냉수와 수도꼭지 내부 침전물 (이하 수도꼭지)을 각각 1개씩 채취하여 총 111 개(온수 37 개, 냉수 37 개, 수도꼭지 37 개)의 검체를 수집하였다. 그리고 다중이용시설 검체는 경기남부지역 보건소에서 의뢰된 142 개 시설의 온수(목욕장 28 개, 숙박시설 13 개, 요양원 30 개, 병원 53 개, 대형건물[용도: 체 육, 쇼핑, 사무 등] 18 개)를 사용하였다.

검체 채취 방법은 냉수와 온수는 수도꼭지를 최대한 냉수 또는 온수 방향으로 옮긴 후 1 2분간 물을 그냥 흘려 보낸 후 무균 채수병 (MEDI-LAND, Korea)에 각각 1L 이상 받은 후 온도를 측정(ACUBA CS-101, China)하였고, 수도꼭지 내부 침전물은 수도꼭지의 망을 제거한 후 멸균 면봉을 수도꼭지 내부로 넣고 3 4회 돌려 채취하였다 (3).

\section{시료 전처리 및 균주 분리}

무균 채수병에 채수 된 검체 $1 \mathrm{~L}$ 를 $0.45 \mu \mathrm{m}$ pore size의 membrane filter (Milipore, Ireland)에 여과한 후 membrane filter를 멸균증 류수 $20 \mathrm{~mL}$ 에 넣고 강하게 진탕하여 부유시켰다. 부유액을 $50^{\circ} \mathrm{C}$ 항온수조(DAIHAN Scientific, Korea)에서 30분간 열처리한 뒤, 검액 $100 \mu \mathrm{L}$ 를 GVPC (Glycine Vancomycin Polymyxin Cycloheximide) 한천배지(bioMérieux SA, France)에 도말하였다. 도말된 배지는 $5 \% \mathrm{CO}_{2}$ 가 공급되는 $37^{\circ} \mathrm{C}$ 배양기(Sanyo, Japan)에서 3일 14일간 배양하면서 전형적인 집락의 특성을 보이는 집락의 형성 여부를 관 찰하였다. 배양된 집락들 중 육안으로 관찰하였을 때, 전체적으로 매끄럽고 볼록한 면을 나타내고 집락이 커지면 음영이 사라지고 중앙과 전체가 불투명해지며, 해부현미경으로 관찰하였을 때 청색, 분홍, 또는 녹색의 음영이 관찰되는 집락을 레지오넬라균으로 의심하여 1차 선별하고 집락의 수를 계수하였다 (11). 
Table 1. Oligonucleotide primers used in this study (11)

\begin{tabular}{ccccc}
\hline Species & Gene & Sequence (5'-3') & Size (bp) & Annealing Temp. ('C) \\
\hline Legionella spp. & 16S rRNA & $\begin{array}{c}\text { AGGGTTGATAGTAAGAGC } \\
\text { CCAACAGCTAGTTGACATCG } \\
\text { GGTGACTGCGGCTGTGG } \\
\text { GGCCAATAGGTCCGCCAACG }\end{array}$ & 386 & 60 \\
\hline
\end{tabular}

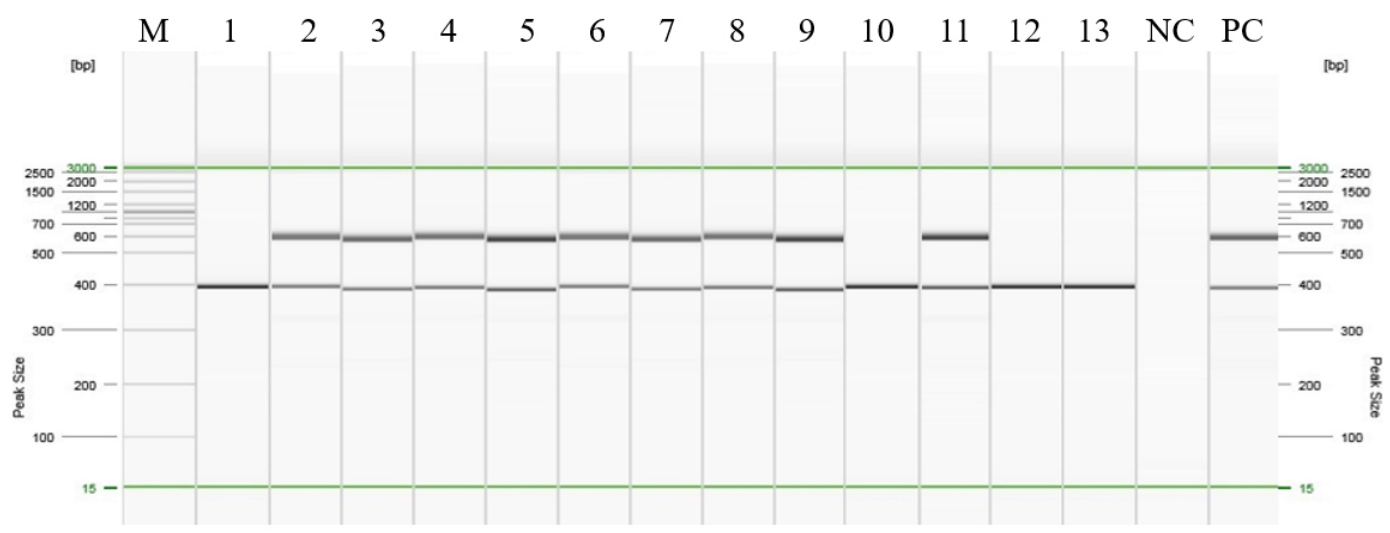

Fig. 1. Amplification of and mip (630 bp) and 16S rRNA (386 bp) DNA from Legionella pneumophila and Legionella spp. with duplex PCR primers. Lane M: marker DNA (100 bp mixed DNA ladder), 1: S5-1, 2: S7-1, 3: S10-1, 4: S11-1, 5: S16-1, 6: S19-1, 7: S20-1, 8: S23, 9: S26-1, 10: S26-2, 11: S29-1, 12: S32-1, 13: S32-2, NC: negative control, PC: positive control ( $L$. pneumophila).

\section{$\mathrm{PCR}$ 을 이용한 $16 \mathrm{~S}$ rRNA, mip 유전자의 검출}

1 차 선별된 집락을 백금이로 취하여 멸균수 $1 \mathrm{ml}$ 에 부유한 후 부유액을 $100^{\circ} \mathrm{C}$ 에서 10 분간 끊여 세균 핵산을 분리하고, $16 \mathrm{~S}$ rRNA 및 mip 유전자(Table 1)에 대한 PCR (Polymerase Chain Reaction, applied biosystems by life technologies, Singapore)을 실시하여 Legionella pneumophila와 Legionella spp.을 분류하였다. 반응조건은 $95^{\circ} \mathrm{C}$ 에서 5 분간 initial denaturation 한 후, $95^{\circ} \mathrm{C}$ 에서 1 분, 6 $0^{\circ} \mathrm{C}$ 에서 1 분, $72^{\circ} \mathrm{C}$ 에서 1 분간의 cycle을 30 회 반복한 후 최종 $72^{\circ} \mathrm{C}$ 에서 5 분간 증폭시켰다. 이 PCR 산물을 QIAxcel (QIAGEN, Switzerland)을 이용하여 전기영동 한 후 유전자의 유무를 확인하였다 (Fig. 1) (11).

\section{분리균주의 혈청학적 동정}

PCR 검사에서 L. pneumophila로 확인된 검체는 GVPC 한천배지에서 순수분리 배양한 후, Legionella Latex Test (Oxoid, United Kingdom)를 이용하여 혈청군을 조사하였다. Oxoid Legionella Latex Test는 레지오넬라균 항체로 코팅된 파란색 라텍스(Latex) 입자를 사용하여 항원과 반응하면 응집되어 눈에 보이는 파란색 덩어리를 형성한다. Oxoid Legionella Latex Test는 시료를 세 혈청군 (L. pneumophila serogroup [sg] 1, L. pneumophila serogroup [sg] 2-14, L. spp. [L. longbeachae 1 및 2, L. bozemanii 1 및 2, L. dumoffii, L. gormanii, L. jordanis, L. micdadei, L. anisa])으로 구분하여 동정할 수 있다. 시험은 슬라이드에 균주 집락 1 2개와 식염수를 1 방울을 넣고 유화시킨 후 라텍스 시약 1 방울과 혼합하여 1 분간 흔들어 강한 응집을 일으키는 것을 양성으로 판독하는 방법으로 수행되었다.

\section{RESULTS DISCUSSION}

\section{아파트의 검체 종류별 레지오넬라균 오염도 조사}

37 개 아파트 중 11 개 아파트에서 레지오넬라균이 검출되었는데 9 개 아파트는 온수에서만 검출되었고, 2 개 아파트는 온수와 수도꼭지 
Table 2. Analysis of Legionella prevalence and water temperature in apartment houses by sample type

\begin{tabular}{lccc}
\hline \multicolumn{1}{c}{ Sample type } & Hot water & Cold water & faucets \\
\hline No. of positive samples / total no. & $11 / 37$ & $0 / 37$ & $2 / 37$ \\
- Positivity (\%) & 29.7 & 0 & 5.4 \\
Temp. ('C) of total samples & $37.6 \sim 59.4$ & $8.0 \sim 25.5$ & - \\
- Temp. ('C) of positive samples & $37.6 \sim 48.8$ & - & - \\
\hline
\end{tabular}

Table 3. Characteristics of Legionella contamination in the examined samples collected from apartment houses

\begin{tabular}{cccccccc}
\hline $\begin{array}{c}\text { Building } \\
\text { name }\end{array}$ & $\begin{array}{c}\text { Building } \\
\text { Age (Year) }\end{array}$ & Sample name & $\begin{array}{c}\text { Sample } \\
\text { type }\end{array}$ & $\begin{array}{c}\text { Collection } \\
\text { time }\end{array}$ & $\begin{array}{c}\text { Temp. } \\
\text { ('C) }\end{array}$ & $\begin{array}{c}\text { Legionella } \\
\text { (CFU/L) }\end{array}$ & Serogroup \\
\hline S5 & 30 & S5-1 & Hot water & April & 37.6 & 200 & spp. \\
S7 & 11 & S7-1 & Hot water & June & 43.3 & 13,000 & sg2-14 \\
S10 & 23 & S10-1 & Hot water & April & 47.6 & 600 & sg1 \\
S11 & 21 & S11-1 & Hot water & April & 45.3 & 800 & sg1 \\
S16 & 21 & S16-1 & Hot water & April & 48.2 & 11,200 & sg2-14 \\
S19 & 22 & S19-1 & Hot water & August & 45.1 & 8,000 & sg2-14 \\
S20 & 21 & S20-1 & Hot water & August & 42.7 & 13,400 & sg2-14 \\
S23 & 21 & S23-1 & Hot water & July & 42.8 & 200 & sg2-14 \\
S26 & 12 & S26-1 & Hot water & June & 41.6 & 5,600 & sg2-14 \\
S26 & 12 & S26-2 & faucets & November & - & Detection & spp. \\
S29 & 11 & S29-1 & Hot water & September & 43.2 & 1,000 & sg2-14 \\
S32 & 8 & S32-1 & Hot water & November & 48.8 & 400 & spp. \\
S32 & 8 & S32-2 & faucets & November & - & Detection & spp. \\
\hline
\end{tabular}

$\mathrm{CFU}=$ Colony Forming Units

내부 침전물(이하 수도꼭지)에서 검출되었다. 냉수에서는 레지오넬라균이 검출되지 않았다 (Table 2, Table 3).

레지오넬라균은 $\mathrm{pH}$ 7.2 8.3, 온도 25.0 45.0의 다양한 환경조건에서 생존이 가능하므로 레지오넬라균의 증식을 예방하기 위해 냉 수는 $20.0^{\circ} \mathrm{C}$ 이하를 유지하고 온수는 $50.0^{\circ} \mathrm{C}$ 이상을 유지할 것을 권고하고 있다 $(12,13)$. 본 연구에서 사용한 공동주택의 냉수 검체의 온도 범위는 $8.0^{\circ} \mathrm{C} 25.5^{\circ} \mathrm{C}$ 이었으며, $20^{\circ} \mathrm{C}$ 이상인 검체가 20 개로 권고치보다 다소 높은 환경이지만 레지오넬라균은 모든 검체에서 검출 되지 않았다. 그리고 온수 검체 전체의 온도범위는 $37.6^{\circ} \mathrm{C} 59.4^{\circ} \mathrm{C}$ 이었으며, 이중 레지오넬라균이 검출된 온수의 온도는 $37.6 ~ 48.8^{\circ} \mathrm{C}$ 이 었다 (Table 2, Table 3).

참고문헌에 의하면 레지오넬라균은 환경에서 순수 분리된 특수한 상태에서는 $50.0^{\circ} \mathrm{C}$ 에 80 124분 정도 노출되면 $90 \%$ 가 사멸하며 $(14,15), 20.0^{\circ} \mathrm{C}$ 에서는 대부분 증식이 멈추는 것으로 보고되고 있지만 $(16)$, 환경수계에서는 $66.0^{\circ} \mathrm{C}$ 의 온수 급수시스템이나 얼어붙은 강물에서 검출되기도 한다 $(14,17)$. 따라서 건물의 레지오넬라균을 예방하기 위해서 온수의 온도를 $50.0^{\circ} \mathrm{C}$ 이상으로 냉수의 온도를 $20.0^{\circ} \mathrm{C}$ 이하로 유지하는 것은 매우 중요하며, 추가적으로 이미 생성된 레지오넬라균을 사멸시키기 위해서 정기적인 소독과 청소가 필요 하다고 판단된다. 또한, 아파트 수도꼭지 검체들 중 2 곳에서 레지오넬라균이 검출되어 감염의 위험이 있으므로 주기적인 청소와 교체가 필요해 보인다.

\section{다중이용시설과 아파트의 레지오넬라균 검출률 비교}

다중이용시설과 아파트의 온수에서 레지오넬라균의 검출률을 비교하면, 아파트는 $29.7 \%$ 이고 다중이용시설은 $20.4 \%$ 이었다. 다중이 용시설 중 목욕장 $42.9 \%$, 숙박시설 $30.8 \%$, 병원 $17 \%$, 요양원 3.3\%, 대형건물(용도: 체육, 쇼핑, 사무 등) $16.7 \%$ 이었다. 아파트 온 수의 검출률은 숙박시설과는 비슷했고 목욕장보다는 낮고, 병원보다는 높았다 (Table 4). 그러나 균수를 비교하면 아파트는 200-13,400 
CFU/L, 다중이용시설은 200-56,000 CFU/L이었으며, 1,000 CFU/L을 초과하는 검체의 비율은 아파트가 $13.5 \%$ (37개 중 5개), 다중 이용시설은 $16.2 \%$ (142개 중 23개)로 다중이용시설이 온수급수설비의 즉각적인 시정조치가 필요한 경우가 더 많았다 (Table 4). 다중 이용시설의 $1,000 \mathrm{CFU} / \mathrm{L}$ 을 초과하는 검체의 비율은 목욕장 $35.7 \%$, 숙박시설 $3.6 \%$, 요양원 $3.3 \%$, 병원 $15.1 \%$, 대형건물 $16.7 \%$ 이었다 (Table 4).

우리나라는 레지오넬라증 환자 발생과 관련된 환경은 “불검출”을 목표로 하고 있으며 공동주택의 급수시설 냉.온수에서 $100 \mathrm{CFU/L}$ 이상 검출 시 재검사 후 소독 청소 등의 대책을 강구하도록 권고하고 있다 (3). 그러나 목욕장의 순환하여 여과하는 욕조수의 경우 레지오넬라 균이 1,000 CFU/L를 초과하지 못하도록 법으로 규제하고 있다 (18). 외국의 사례를 참고하면 관로급수설비(Piped water system)에 대 하여 프랑스는 병원감염 예방을 위한 목표는 $100 \mathrm{CFU/L}$ 미만이지만 공중시설의 목표는 1,000 CFU/L 미만으로 정하고 있고, 독일도 $1,000 \mathrm{CFU} / \mathrm{L}$ 을 검출기준으로 정하고 있다 (Table 5). 네덜란드와 영국도 1,000 CFU/L가 초과되면 소독 등 즉각적인 시정조치를 하도 록 지침으로 정하고 있다 (Table 5) (19).

Table 4. Legionella prevalence of hot water by sampling source

\begin{tabular}{|c|c|c|c|c|c|c|c|}
\hline \multirow[b]{2}{*}{ Sampling source } & \multirow{2}{*}{$\begin{array}{l}\text { Apartments } \\
\text { house }\end{array}$} & \multicolumn{6}{|c|}{ Public-use facilities } \\
\hline & & Sub total & Public bath & Hotel & $\begin{array}{l}\text { Nursing } \\
\text { hospital }\end{array}$ & Hospital & $\begin{array}{l}\text { Large } \\
\text { building }\end{array}$ \\
\hline Legionella (CFU/L) & $200-13,400$ & $200-56,000$ & $200-54,400$ & $400-8,400$ & 56,000 & $600-14,200$ & $2,400-46,000$ \\
\hline $\begin{array}{l}\text { No. of positive } \\
\text { samples/total no. }\end{array}$ & $11 / 37$ & 29/142 & $12 / 28$ & $4 / 13$ & $1 / 30$ & $9 / 53$ & $3 / 18$ \\
\hline - Positivity (\%) & 29.7 & 20.4 & 42.9 & 30.8 & 3.3 & 17.0 & 16.7 \\
\hline $\begin{array}{l}\text { No. of positive } \\
\text { samples }>1,000 \\
\text { CFU/L/total no. }\end{array}$ & $5 / 37$ & $23 / 142$ & $10 / 28$ & $1 / 28$ & $1 / 30$ & $8 / 53$ & $3 / 18$ \\
\hline - Positivity (\%) & 13.5 & 16.2 & 35.7 & 3.6 & 3.3 & 15.1 & 16.7 \\
\hline
\end{tabular}

$\mathrm{CFU}=$ Colony Forming Units

Table 5. Examples of health-based targets and values used as levels for corrective action levels for Legionella in piped water systems (19)

\begin{tabular}{|c|c|c|c|}
\hline Country & Value (CFU/L) & Comment & Reference \\
\hline \multirow{3}{*}{ France } & $<50$ & - Target where at-risk patients are hospitalized & \multirow{3}{*}{$\begin{array}{l}\text { Ministère de la Sante et } \\
\text { des Solidarités (2005) }\end{array}$} \\
\hline & $<100$ & - Target for prevention of nosocomial infection & \\
\hline & $<1,000$ & - Target for general public facilities & \\
\hline Germany & 1,000 & & DVGW (2004) \\
\hline \multirow[b]{2}{*}{ The Netherlands } & 100 & - Guideline target & \multirow[b]{2}{*}{ VROM (2004) } \\
\hline & $>1,000$ & $\begin{array}{l}\text { - Immediate action is needed to prevent closure of (part of) } \\
\text { system involved }\end{array}$ & \\
\hline \multirow{3}{*}{ United Kingdom } & $<100$ & - Guideline target & \multirow{3}{*}{ HSE (2004) } \\
\hline & $100-1,000$ & $\begin{array}{l}\text { - Action depends on whether just one or two or majority of } \\
\text { samples are positive; review of control measures and risk } \\
\text { assessment required; possible disinfection }\end{array}$ & \\
\hline & $>1,000$ & $\begin{array}{l}\text { - Immediate review of control measures and risk assessment } \\
\text { requires; possible disinfection }\end{array}$ & \\
\hline \multirow[b]{2}{*}{ United States } & $>10,000$ & - Prompt cleaning and/or biocide treatment of the system & \multirow[b]{2}{*}{ OSAHD (2005) } \\
\hline & $>100,000$ & $\begin{array}{l}\text { - Immediate cleaning and/or biocide treatment; take prompt } \\
\text { steps to prevent employee exposure }\end{array}$ & \\
\hline
\end{tabular}

$\mathrm{CFU}=$ Colony Forming Units 
Table 6. Comparison of Legionella prevalence of the domestic hot water by age of apartment houses

\begin{tabular}{lcccc}
\hline \multicolumn{1}{c}{ Age (Year) } & Total & $1-10$ & $11-20$ & $>20$ \\
\hline No. of positive samples / total no. & $11 / 37$ & $1 / 15$ & $3 / 9$ & $7 / 13$ \\
- Positivity (\%) & 29.7 & 6.7 & 33.3 & 53.8 \\
\hline
\end{tabular}

아파트 노후도 따른 레지오넬라균 검출률 분석

아파트 노후도에 따른 레지오넬라균 검출률은 10년 이하는 $6.7 \%, 10$ 년 초과 20 년 이하는 $33.3 \%, 20$ 년이 초과는 $53.8 \%$ 로 아파트가 노후화될 수록 검출률이 높아지는 양상을 보여(Table 6) 기존의 연구 결과와 일치하였다 (20).

이러한 이유는 레지오넬라균이 배관이 노후되어 막힌 부분이나 저장탱크, 정체된 부분에서 잘 증식하기 때문으로 판단된다 (6). 따라서 평소에 저장탱크나 배관을 청소하고 영양물질을 통제하여 미생물의 번식을 최소화할 필요가 있다 (21). 또한 건물 배관 설계 시 배관의 막힌 부분을 가능한 짧게 하고, 파이프 배관 시설에 쓰이는 재료를 부식에 강하고 미생물 번식을 최소화할 수 있는 소재로 사용하여 건물 의 노후화에 따른 배관 막힘이나 미생물 번식을 사전 예방할 필요가 있다 $(22,23)$.

\section{분리균주의 혈청학적 분석}

아파트 온수에서 분리된 균주의 혈청형을 분석한 결과 총 13개의 균주가 분리되었는데 L. pneumophila sg1 2개, sg2-14 7개, L. spp. 4개이었다 (Table 3). 레지오넬라증의 약 80 90\%는 L. pneumophila sg1이 원인균이다. 아파트에서 분리된 총 12개의 균주 중 2개의 균주가 sg1으로 동정되어 가정에서도 레지오넬라증에 감염될 위험성이 존재한다는 것을 시사하였다 (24).

\section{CONCLUSION}

본 연구는 2020년도 1월부터 12월까지 37개 아파트의 냉•온수와 수도꼭지 내부 침전물 각각 1개씩 총 111 개 검체와 142 개 다중이용 시설 온수 각 1 개씩 총 142 개 검체를 수집하여 레지오넬라균 오염도를 조사하였다.

1. 아파트의 레지오넬라균 오염도를 검체별로 분석한 결과 각각 37 개 검체 중 온수는 11 개, 수도꼭지는 2 건 검출되었고 냉수에서는 검 출되지 않았다. 따라서 아파트는 온수급수설비의 레지오넬라균 관리가 가장 시급한 것으로 나타났다.

2. 아파트와 다중이용시설 온수의 레지오넬라균 오염도를 비교한 결과 아파트는 $29.7 \%$, 다중이용시설은 $20.4 \%$ 이었으나, 균의 수가 $1,000 \mathrm{CFU} / \mathrm{L}$ 를 초과하여 검출된 비율은 아파트(13.5\%)가 다중이용시설(16.7\%)에 비해 낮다.

3. 아파트는 노후도가 클수록 레지오넬라균 검출률이 높아져 10년 이하는 $6.7 \%, 10$ 년 초과 20년 이하는 $33.3 \%, 20$ 년 초과는 $53.8 \%$ 의 검출률을 보였다.

4. 혈청형을 분석한 결과 레지오넬라증 원인균의 약 80 90\%를 차지하는 L. pneumophila sg1이 13 개 균주 중 2개에서 동정되었다.

우리나라의 레지오넬라증 신고건수는 최근 큰 폭으로 증가하고 있다 (8). 국내 레지오넬라 폐렴 발생은 대부분 산발적으로 발생하는 사례 들이고, 대규모 유행은 아직까지 확인된 바 없으나 외국의 경우 대규모 유행 발생과 그로 인한 사망 사례들이 꾸준히 보고되고 있다 (20). 따라서 레지오넬라 폐렴의 대규모 유행을 예방하기 위해 레지오넬라증 발생 위험이 있는 환경들에 대해 지속적인 관리가 필요하다. 아파 트는 우리나라 대표적인 주거형태로 레지오넬라균 방재 대책이 시급하며, 관리 방법으로는 온수 급수배관의 주기적인 청소·소독과 노후 배관의 교체, 수도꼭지와 샤워헤드의 주기적 교체 또는 급수배출구에 필터 장착 등이 있다 (25).

\section{REFERENCES}

1) Fraser DW, Tsai TR, Orenstein W, Parkin WE, Beecham HJ, Sharrar RG, et al. Legionnaires' disease: Description of an epidemic of pneumonia. N Eng/ J Med 1977; 297: 1189-97. 
2) Kim JS, Lee SW, Shim HS, Oh DK, Cho MK, Oh HB, et al. An outbreak of Legionellosis in ICU of K hospital, Korea. Korean J Epidemiol 1985:7:44-58

3) Korea Disease Control and Prevention Agency. 2021 Respiratory Infectious Diseases Management Guidelines. Korea Disease Control and Prevention Agency: Chungju-si, Republic of Korea: 2021:79-118.

4) Korea Disease Control and Prevention Agency. Infectious disease portal [URL: http://www.kdca.go.kr/npt/]

5) Korea Disease Control and Prevention Agency. Epidemiological investigation of infectious diseases in Korea annual reaport 2018. Korea Disease Control and Prevention Agency: Chungju-si, Republic of Korea: 2019;213-30.

6) Lee SJ. Comparison of planning and applicability of domestic hot water systems considering prevention of Legionella infections in apartment building. Seoul National University: 2018;1-25.

7) Enforcement decree of the housing act, Article 3 (Types and Scope of Multi-Family Housing). 1. [https://www.law.go.kr/ LSW/main.html]

8) Statistics Korea. Population and housing census. [https://kosis.kr/statHtml/statHtml.do?orgld=101\&tblld=DT_1JU1501\&ww_cd= \&list_id=\&seqNo=\&lang_mode=ko\&language=kor\&obj_var_id=\&itm_id=\&conn_path=|2]

9) Housing act, Article 2 (Definitions). 3. [https://www.law.go.kr/LSW/main.html]

10) Enforcement decree of the infectious disease control and prevention act. Article 24 (Facilities Requiring Disinfection). 13. [https://www.law.go.kr/LSW/main.html]

11) National Institute of Environmental Research. Analysis method for Legionella in environment. National Institute of Environmental Research: Chungju-si, Republic of Korea: 2013;19-29.

12) ECDC. European Technical Guidelines for the Prevention, Control and investigation, of infections caused by Legionella species. European Centre for Disease Prevention and Control: Stockholm: 2017.

13) EPA. Technologies for Legionella control in premise plumbing systems. Scientific literature review. Environmental Protection Agency: D.C., United States: 2016

14) Dennis PJ, Green D, Jones BP. A note on the temperature tolerance of Legionella. J App/Bacterio/1984;56:349-50.

15) Schulze-Röbbecke R, Rödder M, Exner M. Multiplication and killing temperatures of naturally occurring legionellas. Zentralb/ Bakteriol Mikrobiol Hyg B 1987;184:495-500.

16) Dennis PJ, Lee JV. Differences in aerosol survival between pathogenic and non-pathogenic strains of Legionella pneumophila serogroup 1. J App/ Bacterio/ 1988;65:135-41.

17) Söderberg MA, Rossier O, Cianciotto NP. The type II protein secretion system of Legionella pneumophila promotes growth at low temperatures. J Bacterio/2004;186:3712-20.

18) Enforcement rule of the public health control act, Attached Table 2. Standards and methods of analyzing water quality, etc. for bath water of public bath.

19) World Health Organization. Legionella and the prevention of legionellosis. World Health Organization: Geneva, Switzerland: 2007;57-68.

20) Borella P, Montagna MT, Romano-Spica V, Stampi S, Stancanelli G, Triassi M, et al. Legionella Infection risk from domestic hot water. Emerg Infect Dis 2004;10:457-64

21) Momba MNB, Kfir R, Venter SN, Cloete TE. An overview of biofilm formation in distribution systems and its impact on the deterioration of water quality. Water S A 2000;26:59-66. 
22) Sacchetti R, De Luca G, Zanetti F. Influence of material and tube size on DUWLs contamination in a pilot plant. New Microbio/2007:30:29-34.

23) Rogers J, Dowsett AB, Dennis PJ, Lee JV, Keevil CW. Influence of temperature and plumbing material selection on biofilm formation and growth of Legionella pneumophila in a model potable water system containing complex microbial flora. App/ Environ Microbio/ 1994;60:1585-92.

24) Tkatch LS, Kusne S, Irish WD, Krystofiak S, Wing E. Epidemiology of Legionella pneumonia and factors associated with Legionella related mortality at a tertiary care center. Clin Infect Dis 1998;27:1479-86.

25) Bates MN, Maas E, Martin T, Harte D, Grubner M, Margolin T. Investigation of the prevalence of Legionella species in domestic hot water systems. NZMed J 2000;113:218-20. 